\title{
Ostracoda of the Holsteinian Interglacial in Jutland, Denmark
}

BY

DAVID NORMAN PENNEY 


\section{Abstract}

Ostracoda are described from several marine Holsteinian deposits in Jutland, Denmark. The faunas are extremely uniform all over Jutland. Very little difference is seen between them and the faunas present in Late Elsterian deposits of the same area. They are largely boreal in aspect, but contain a few species from warmer realms. With the exception of Callistocythere $\mathrm{sp}$ and Semicytherura sp, all the species are extant, though Carinocythereis whitei and Pterygo- cythereis coronata do not live in Danish inshore waters today. The environment at all the investigated localities was one of open, shallow waters (10-30 m depth) and normal marine salinities. No shallower water facies have as yet been identified. The Holsteinian ostracod faunas of Denmark are analogous to those recorded in North Germany, and show similarities to those reported from Mid-Pleistocene deposits in Great Britain. 


\section{Introduction}

In recent years detailed surveys of the marine Late Elsterian and Holsteinian deposits of Jutland, Denmark, have been made. In the course of these surveys pollen (Andersen 1963, 1965) and Foraminifera (Buch 1955, Jensen \& Knudsen 1984, Knudsen 1987 and this volume, Kronborg \& Knudsen 1985) have been studied, and amino acid determinations have been undertaken on marine molluscs from some of the sites (Miller \& Mangerud 1986), confirming a Holsteinian age for most of them. The material examined by $\mathrm{Dr}$ K. L. Knudsen was also found to contain ostracods, and the residues were kindly made available to me for the analysis and description of the ostracod assemblages. The present paper thus augments Knudsen's several articles on the marine Holsteinian deposits of Denmark.

Very little work has been undertaken on Mid- to Late Pleistocene marine ostracods in Northwest Europe. The Hoxnian (Holsteinian) Ostracoda of the Brickearths of the River Nar Valley in Norfork, England, have been examined on several occasions (see e.g. Lord \& Robinson 1978). The Bridlington Crag (Catt \& Penny 1966, Neale \& Howe 1975) and the Speeton Shell Bed (Edwards 1982) have also yielded Ostracoda. both deposits have conventionally been dated as Hoxnian, but the Bridlington Crag is clearly a cold water deposit with ostracod faunas which cannot be considered as indicating interglacial conditions. Robinson (in West et al. 1984) has described the Ostracoda of a Mid-Pleistocene (Holsteinian?) channel fill sequence at Earnley, Sussex. Ipswichian (Eemian) ostracods have been investigated at Shortalstown, Co. Wexford, Ireland (Whatley, in Colhoun \& Mitchell 1971), Selsey, Sussex (Whatley \& Kaye 1971), and in the Burtle Beds of Somerset (Whatley, in Kidson et al. 1978). Whittaker (in Kirby \& Oele 1975) reported on the Ostracoda in the 'Late Pleistocene' graded sediments of the Sandettie-Fairey Bank in the English Channel off Ostend.

Woszidlo (1962) described a fauna from the Holsteinian deposits of Schleswig-Holstein and Esbjerg, Denmark, on the European mainland. Bassiouni (1965) has also listed the ostracods of the 'Esbjerg Yoldia Clay', but his material does not appear to constitute a complete fauna. The Esbjerg deposits were originally assigned to the Holsteinian interglacial (e.g. Hansen 1965), but recent amino-acid measurements on mollusc shells would suggest a pre-Holsteinian age (Miller \& Mangerud 1986). Unfortunately, none of the material examined by the author from Esbjerg yielded any ostracods. There are no other published accounts of interglacial marine Ostracoda in Northwest Europe. 


\section{Material and methods}

The sites chosen for this study are all located in Jutland (fig. 1). Tornskov and Inder Bjergum are in southwest Jutland, Kås Hoved is in the Limfjord area, and Hadsten and Rugård are in East Jutland.

The samples used are the same as those examined by Knudsen (1987, this volume, Jensen \& Knudsen 1984, Kronborg \& Knudsen 1985: all sites) and Buch (1955: Tornskov and Inder Bjergum). The results may, therefore, be directly compared, both qualitatively and quantitatively. The preparation techniques used on the raw samples were described in detail by Meldgaard \& Knudsen (1979). The ostracods were obtained in part from the light foraminiferal concentrates and in part by picking the residues from which the Foraminifera had been obtained. The total assemblage, perfect and imperfect specimens alike, was picked in each sample in order to obtain a representative fauna, as far as was possible. Thus all immature moult stages (recorded as instars) were recorded along with the larger adult valves. Articulated valve-pairs (carapaces) were only very occasionally found in the analysed material. As studies on Quaternary and living Ostracoda have shown that certain types of population age-structure are indicative of either life- or death-assemblages (Whatley 1983), the above approach enabled the in-situ status of each species and overall fossil community to be assessed, thus facilitating palaeoenvironmental interpretation. 


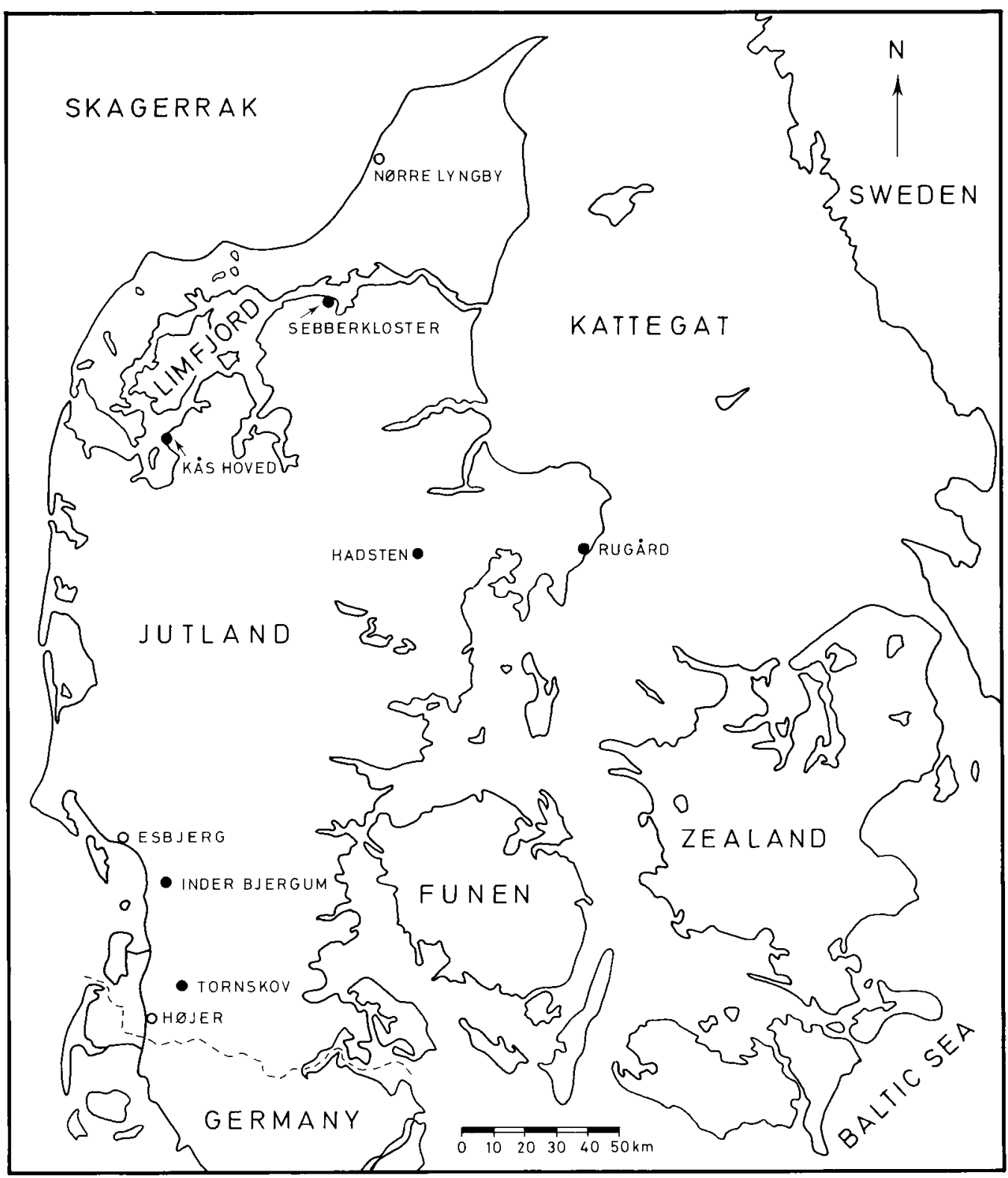

Fig. 1. Map of Denmark showing place names referred to in the text. Filled circles $=$ sites examined in this study. Open circles $=$ other sites. 


\section{Tornskov}

The Tornskov boring (Danish Geological Survey, File no. 157. 243) was described in detail in Andersen (1963). A total of 68 samples were examined from the marine sediments between $94.7 \mathrm{~m}$ and $13.7 \mathrm{~m}$ depth ( $72.7 \mathrm{~m}$ below sea-level to $8.3 \mathrm{~m}$ above sealevel). Only 24 of the samples yielded Ostracoda (fig. 3). When compared with the occurrence of Foraminifera, which were present in all of the samples (Knudsen, this volume), the record of Ostracoda must be considered disappointing. To what extent this is a function of the palaeoenvironments in the Tornskov area during deposition cannot now be fully determined, but it could be due to the sediment accumulation rate, $\mathrm{di}$ agenesis, laboratory processing of the samples, or a combination of these factors. The small sample size ( $100 \mathrm{~g}$ dry weight) has definitely influenced both the number of species (18) and the number of specimens (1 carapace and 247 valves: fig. 3) present in the analysed material.

\section{Ostracoda}

Figure 3 should be examined in conjunction with Knudsen's (this volume: fig. 3) foraminiferal data. The boring penetrated a thick, dominantly argillaceous sequence. The Elsterian deposits at the base of the borehole (foraminiferal zones $\mathrm{A}$ and $\mathrm{B}$ ) were sandier and contained no Ostracoda. Foraminiferal zone $\mathrm{C}$ contained ostracod assemblages characterized by Robertsonites tuberculatus and Acanthocythereis dunelmensis, with Sarsicytheridea punctillata, $S$. bradii, Cytheropteron latissimum, and Elofsonella concinna. There was a trend of in- creasing diversity and density upwards through the zone, to a maximum of 8 species and 108 valves in sample no. $76(75 \mathrm{~m})$.

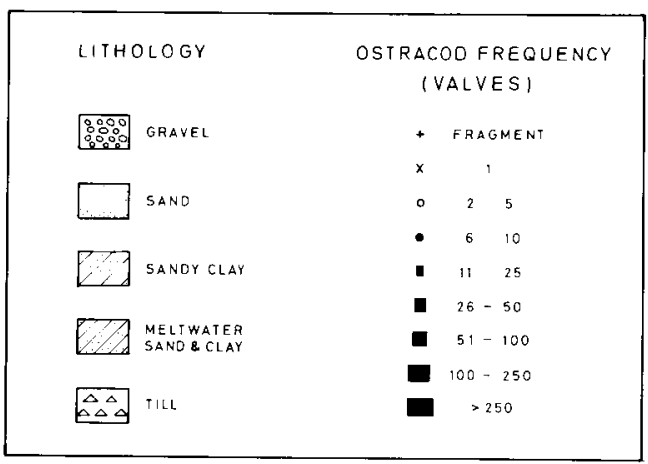

Fig. 2. Explanation of symbols used in the ostracod diagrams.

The ostracods in the remainder of the borehole distinguished themselves immediately from those in foraminiferal zone $\mathrm{C}$ in both their scarcity and species composition (fig. 3). Ostracoda were extremely rare in foraminiferal zone D. They occurred only sporadically and in small numbers up to 67 $m$ (sample no. 68), and none were found between $66 \mathrm{~m}$ and $44 \mathrm{~m}$. Knudsen's (this volume) foraminiferal assemblages were also rather sparse above $70 \mathrm{~m}$ (sample no. 71). The only species present were Robertsonites tuberculatus, Sarsicytheridea bradii, Cythere

Fig. 3. Distribution of Ostracoda in the Tornskov boring. The symbols used in the diagram are explained in fig. 2. 


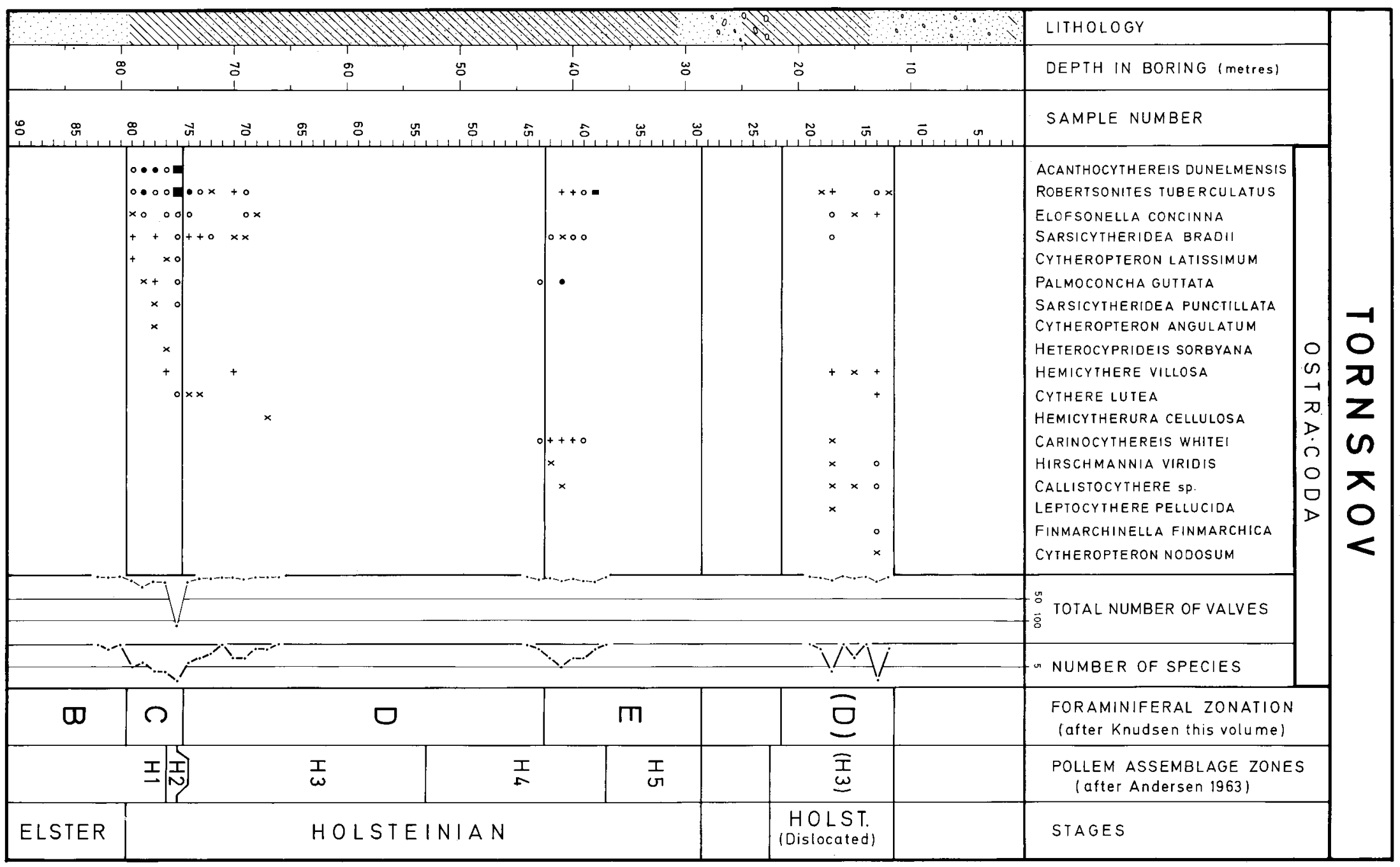


lutea, Hirschmannia viridis, Hemicythere villosa, and Hemicytherura cellulosa. Acanthocythereis dunelmensis did not occur above foraminiferal zone $\mathrm{C}$ (fig. 3 ).

The samples between $44 \mathrm{~m}$ and $39 \mathrm{~m}$ depth were characterized by the presence of Carinocythereis whitei and Palmoconcha guttata (as the finely punctate Scandinavian form), with Sarsicytheridea bradii and Robertsonites tuberculatus. This interval corresponded roughly to the base of foraminiferal zone $E$ (Knudsen this volume, fig. 3). The remainder of the zone was barren of Ostracoda.

The upper marine interval between $22 \mathrm{~m}$ and $13.7 \mathrm{~m}$ contained sparse ostracod assemblages, which resembled those found at the base of foraminiferal zone D (fig. 3), with the noticeable addition of Callistocythere sp.

\section{Palaeoenvironment}

The ostracods present in the Tornskov boring were indicative of cold temperate, shallow waters of normal marine salinity. The four most important species in foraminiferal zone C: Robertsonites tuberculatus, Sarsicytheridea bradii, S. punctillata, and Acanthocythereis dunelmensis, are widely distributed littoral and inner neritic forms with eurythermal tolerance, and they occur commonly in North Atlantic boreal and arctic faunas (e.g. Neale 1974, Neale \& Howe 1975, Lord 1980). Elofsonella concinna, Cytheropteron latissimum, and the finely punctate form of Palmoconcha guttata are also inner neritic in habit, but have their northern limit of distribution in East Finmark, at about $70^{\circ} \mathrm{N}$ in the eastern North Atlantic (Norman 1891, Sars 1928, Elofson 1941, Whatley \& Masson 1979). E. concinna extends into the arctic province in the western North Atlantic, but has not been recorded live in the eastern arctic (e.g. Neale \& Howe 1975). All these species are very commonly found together in the Skagerrak and Kattegat today (Elofson 1941). The as- semblages lacked certain southern species that have their northern limit of distribution in the North Sea (Neale 1974). They may, therefore, indicate conditions similar to, but a little cooler than they are in the North Sea today.

The ostracod, pollen, and foraminiferal evidence are compatible in this section of the boring. Andersen (1963) recognised a typical pioneer open vegetation-type (pollen zone H1), which was succeeded by a $P i$ nus dominated forest flora (pollen zone $\mathbf{H} 2$ ), and Knudsen (this volume) interpreted foraminiferal zone $\mathrm{C}$ as the first stage of the interglacial. She placed the Late ElsterianHolsteinian boundary at $79.5 \mathrm{~m}$ depth, at the base of this zone (fig. 3).

The ostracod species found in foraminiferal zone $\mathrm{D}$ and the dislocated unit near the top of the borehole (fig. 3) are nearly all present in the North Sea today, and climatic conditions must, therefore, have been similar. As only immature moult stages were found, the assemblages may represent low energy death assemblages. In addition, their sparsity may have resulted from an extremely high sedimentation rate consequent on a rapid rise in sea-level, in an inshore area partially protected by a series of islands and headlands, as is the situation in the German Bight today. Some of the species are essentially euryhaline and phytal in habit (e.g. Hirschmannia viridis and Hemicythere villosa), but the majority are benthonic and require salinities greater than $30 \%$ outside the Baltic Sea. The Callistocythere species is a distinctive small, ornamented form, which is at present undescribed. Its distribution and stratigraphical significance in Northwest Europe will be returned to in the discussion.

Ostracoda reappeared in the borehole at the top of foraminiferal zone D. This coincided with a marked increase in the numbers of Foraminifera in the samples (Knudsen, this volume, fig. 3), and may indicate that the sedimentation rate had fallen. Of particular interest in the interval between 43 $\mathrm{m}$ (sample no. 44) and $38 \mathrm{~m}$ (sample no. 39) 
was the almost total absence of phytal, euryhaline species, and the presence of Carinocythereis whitei. This species inhabits Atlantic coasts from south Britain to Northwest Africa, and is widespread in the Mediterranean. It is a benthonic species, typically living on sand and silty substrates from 2-60 m depth (Athersuch et al. 1985). Its presence in foraminiferal zone $\mathrm{E}$ may indicate slightly warmer conditions than existed in the other foraminiferal zones. It is also noticeable that a climax forest-type vegetation (top of pollen zone $\mathrm{H} 4$ ) was being approached at this level in the borehole (Andersen 1963). The foraminiferal zone $\mathrm{E}$ ostracod assemblages correspond to shallow sublittoral, marine associations. Knudsen (this volume) considered the foraminiferal assemblages at the base of this zone to re- present a more protected environment than either in zone D or the top of zone E. Although the ostracod assemblages included both adult valves and final moult stages, their sparsity rendered any attempt to assess whether they represented life or death assemblages highly conjectural. Knudsen's conclusions cannot, therefore, be either confirmed or rejected.

No Ostracoda were found at the top of foraminiferal zone $\mathrm{E}$ (fig. 3). The foraminiferal assemblages were also sparse (Knudsen this volume), and the presence of badly etched and pyritized Foraminifera in the residues was witness to the detrimental effects of diagenesis on the faunas. Any Ostracoda present were probably destroyed by these processes. 


\section{Inder Bjergum}

The Inder Bjergum No. 2 boring (Geological Survey File no. 140.82b) was described in detail by Buch (1955). It penetrated a 58 $\mathrm{m}$ thick sequence of marine interglacial deposits between $10.23 \mathrm{~m}$ and $65.23 \mathrm{~m}$ below sea-level (fig. 4). A total of 24 samples were examined from this sequence, fourteen of which yeilded Ostracoda.

\section{Ostracoda}

Of the 19 species present in the interglacial deposits at Inder Bjergum, 12 were also recorded at Tornskov. A total of 1865 ostracod valves were found, 1090 of which were obtained from sample no. 18 (fig. 4). No Ostracoda were present below $-65.7 \mathrm{~m}$ (sample no. 25) and above $-14.8 \mathrm{~m}$ (sample no. 9). Rich assemblages occurred in the interval between $-38.2 \mathrm{~m}$ and $-57.7 \mathrm{~m}$ (sample nos 17 to 20 ).

Very sparse assemblages were found below $-60.46 \mathrm{~m}$ (fig. 4). The assemblages in the succeeding samples were reminiscent of those found in foraminiferal zone $\mathrm{C}$ at Tornskov (fig. 3), but there were certain striking differences. In particular, Cluthia cluthae occurred between $-60.73 \mathrm{~m}$ (sample no. 21) and $-39.48 \mathrm{~m}$ (sample no. 18), its distribution overlapping above $-43.23 \mathrm{~m}$ (sample no. 19) with Palmoconcha laevata, Hirschmannia viridis, and Leptocythere spp. The most important species in this interval in the boring were Robertsonites tuberculatus, Acanthocythereis dunelmensis, Cytheropteron latissimum, Sarsicytheridea punctillata, $S$. bradii, and Elofsonella concinna, with Palmoconcha guttata occurring above -52.7 m (sample no. 20).

\section{Palaeoenvironment}

The Ostracoda of the Inder Bjergum No. 2 boring were indicative of cold temperate, shallow waters of normal marine salinity, i.e. similar environmental conditions as existed during the deposition of foraminiferal zone $\mathrm{C}$ at Tornskov. The pollen and for aminiferal evidence (Andersen 1963, Buch 1955 , Knudsen this volume) would place the Elsterian-Holsteinian boundary at $-42.3 \mathrm{~m}$ (sample no. 19). No sharp boundary could, however, be distinguished on the basis of the ostracod assemblages. Rather, there was a gradual change in the faunas between $-60.7 \mathrm{~m}$ (sample no. 21) and $-39.5 \mathrm{~m}$ (sample no. 18), as certain species of arctic affinity died out, to be replaced by boreal species.

The arctic species included Cluthia cluthae, which has its southern limit of distribution today in East Finmark, North Norway (Norman 1891, Neale 1973). Earlier records of this species from as far south as the Celtic Sea have proved to be of Cluthia keiji, a related but more thermophilous species (Neale 1975). Another arctic species is $\mathrm{He}$ terocyprideis sorbyana, which was also found in foraminiferal zone $\mathrm{C}$ at Tornskov. This species lives today in the Baltic Sea (Hirschmann 1912, Elofson 1941, Rosenfeld 1977), but its main distribution is in the arctic, and Hirschmann (1912) considered it to be a glacial relict species in the Baltic. Palmoconcha laevata, $P$. guttata, Cytheropteron latissimum, Hirschmannia viridis, and Leptocythere spp., on the other hand, all have their northern limit of distribution in East Finmark (e.g. Norman 1891, Sars 1928, Elofson 1941, Whatley \& Masson 1979). 


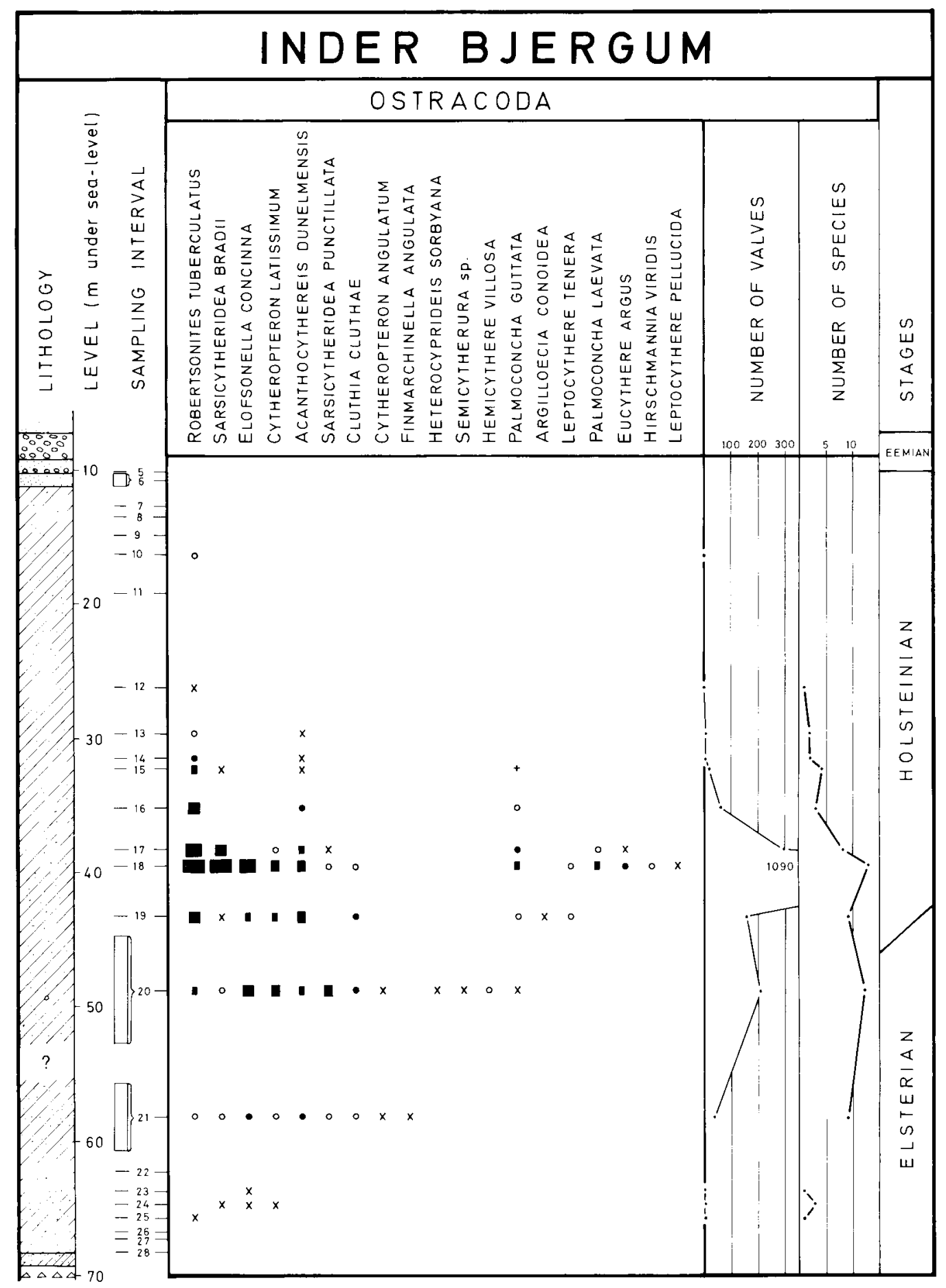

Fig. 4. Distribution of Ostracoda in the Inder Bjergum No. 2 boring. Symbols used in this diagram are explained in fig. 2. 
The assemblages in sample nos 20 and 21 were, thus, comparable to the ostracod faunas of the northern Norwegian province today, whereas the faunas found above -43.2 m (sample no. 19) reflected slightly warmer conditions. The differences in the assemblages were, however, very slight, as the most important species were the same both above and below the Elsterian-Holsteinian boundary (fig. 4). 


\section{Kås Hoved}

Marine deposits are exposed at the base of a cliff-section at Kås Hoved in the Limfjord (fig. 1). These massive dark grey silty clays underlie a sandy till, which was deposited from the northeast (Jensen \& Knudsen 1984). The sediments are bioturbated and contain worm burrows. They are full of articulated shells of Nuculana (Leda) pernula, a species which lives at water depths of greater than $15-20 \mathrm{~m}$. The marine sequence contains boreal shelf foraminiferal faunas, also from a water depth of more than $15 \mathrm{~m}$. The deposits are considered to be Holstei- nian in age (Jensen \& Knudsen 1984, Miller \& Mangerud 1986).

\section{Ostracoda}

A total of 4 ostracod carapaces and 2762 valves belonging to 18 species, were found in the 6 samples examined from the marine clays at Kås Hoved (fig. 5). Sample no. 755 was almost barren, but the other samples contained from 327 to 922 valves in each. The assemblages were totally dominated by

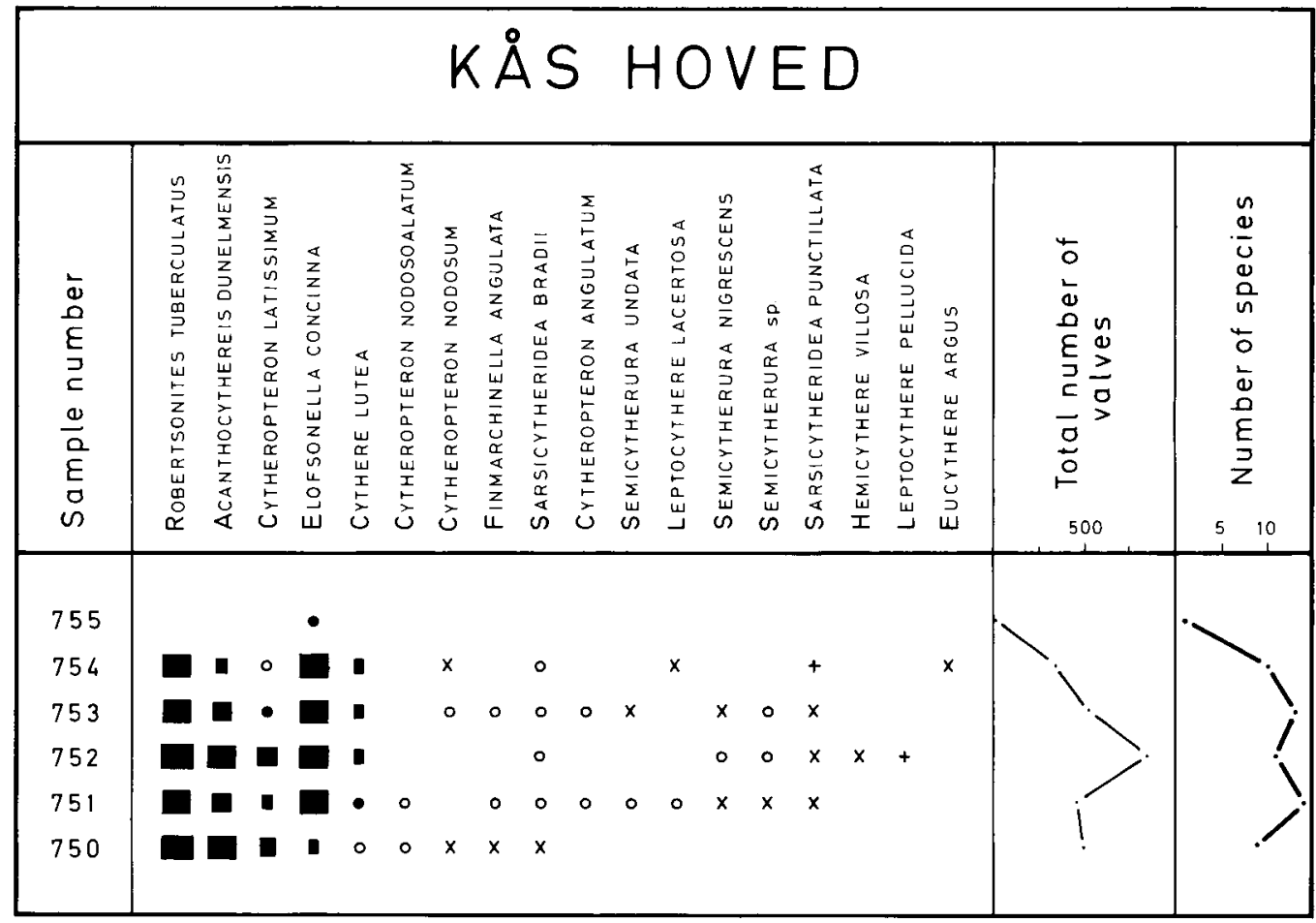

Fig. 5. Distribution of Ostracoda in the Holsteinian deposits at Kås Hoved (Limfjord). Sample numbers are the same as those used by Jensen \& Knudsen 1984. The symbols used are explained in fig. 2. 
adult valves and immature moult stages of Robertsonites tuberculatus, Acanthocythereis dunelmensis, Elofsonella concinna, and Cytheropteron latissimum, which together accounted for $94 \%$ to $98 \%$ of the total in each sample. The only other species of importance, Cythere lutea, showed an increase from $0.3 \%$ of the assemblage in sample no. 750 to $3.7 \%$ in sample no. 754. Elofsonella concinna also increased (4.5\% to $31 \%)$, while Acanthocythereis dunelmensis (26\% to $13 \%$ ) and Cytheropteron latissimum ( $7.5 \%$ to $1 \%$ ) both decreased in importance.

The assemblages contained an as yet undiscribed Semicytherura species. This is a small, slightly elongated form, with a very distinctive pattern of punctae in the dorsocentral part of the valve (Plate 2, figs. 5,6).

\section{Palaeoenvironment}

The ostracod assemblages present in the Kås Hoved deposits are cold temperate, shallow shelf faunas. They were very similar to the assemblages found in foraminiferal zone $\mathrm{C}$ at Tornskov, and in the Inder Bjergum No. 2 boring (figs $3 \& 4$ ). Most of the species are benthonic in habit, but a few phytal forms, including Hemicythere villosa and Semicytherura nigrescens, were present. These species may have been washed in from shallower waters. The changes in faunal composition described above may have been temperature related, suggesting a slight warming, but could also indicate a slight reduction in water depth upwards in the profile. Knudsen's (Jensen \& Knudsen 1984) foraminiferal assemblages were very uniform in composition, and showed no shallowing trend. 


\section{Rugård}

Kronborg \& Knudsen (1985) gave a preliminary account of the Quaternary section exposed in the coastal cliff at Rugård in eastern Jutland (fig. 1). These deposits were divided up into an upper and lower glacial series, separated by marine sediments. The latter rested unconformably on the lower glacial series and were up to $2.5 \mathrm{~m}$ thick. They comprised a lower fine silty sand with peat inclusions and an upper oyster-rich clay (Kronborg \& Knudsen 1985). The foraminiferal assemblages in the marine deposits recorded a transition from shallow brackish water conditions in the silty sands to a more open marine environment with water depths of greater than $30 \mathrm{~m}$ in the oyster bearing clays. These deposits were tentatively placed in the Holsteinian interglacial (Kronborg \& Knudsen 1985), an interpretation which has recently been supported by thermoluminescence measurements on the marine sediments at Rugård (Knudsen 1987).

\section{Ostracoda}

No Ostracoda were present in either the brackish water horizon at Rugård, or in the lower part of the oyster-bearing clays. The Foraminifera were also very badly preserved in these layers (samples F6-F2: fig. 6). A total of 405 valves were found in sample F1, belonging to 9 species. Elofsonella concinna dominated $(87 \%)$, and the only other species of importance was Robertsonites tuberculatus $(10 \%)$. Of note was the presence of Krithe praetexta and a single adult valve of Cytheropteron inornatum. Neither of these two species have been found in any other Holsteinian marine deposit in Jutland.

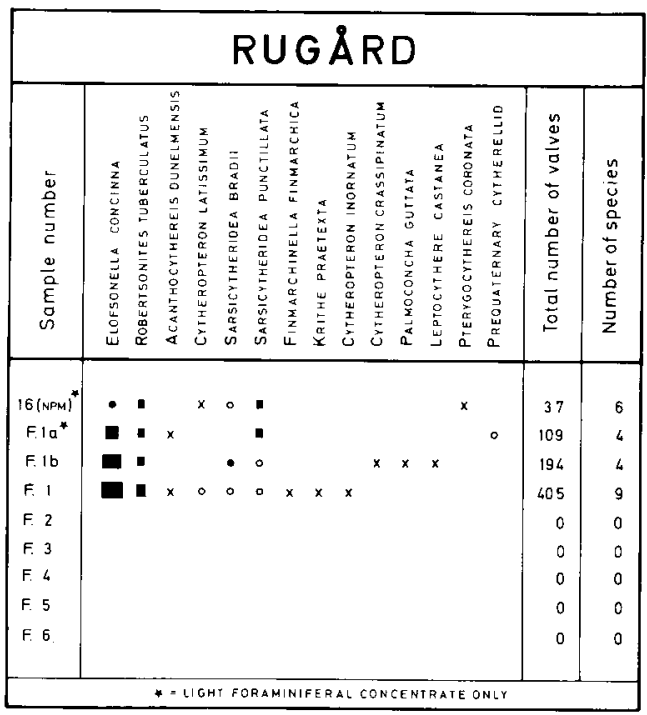

Fig. 6. Distribution of Ostracoda in the Holsteinian deposits at Rugård (East Jutland). Sample nos F1-F6 are the same as those used by Kronborg \& Knudsen 1985. Nos NPM-16 and F1a are the same as those given in Knudsen 1987. The symbols are explained in figure 2.

Three further samples were examined from the upper part of the oyster-bearing clays at Rugard (fig. 6). These contained ostracod assemblages which resembled that found in sample no. F1, with some noteworthy additions. Sarsicytheridea punctillata was an important species in two of the samples (nos F1a and 16). In addition, three adult valves of a pre-Quaternary cytherellid were found in sample no. F1a, an adult valve of Cytheropteron crassipinatum in sample no. F1b, and a juvenile valve of Pterygocythereis coronata in sample no. 16 (fig. $6)$. 


\section{Palaeoenvironment}

The ostracod assemblages present in the Rugård deposits resembled those present in the Tornskov and Inder Bjergum borings and at Kås Hoved, but they contained a few species which live in fairly deep waters in the North Atlantic today. These included Krithe praetexta, which has been found from $50 \mathrm{~m}$ to $500 \mathrm{~m}$ depth in Northwest Europe (Athersuch 1982), and Cytheropteron inornatum, which occurs from $25 \mathrm{~m}$ to $50 \mathrm{~m}$ depth off western Britain (Whatley \& Masson 1979), but is also known from deeper waters in the Adriatic (Bonaduce et al. 1975).

Pterygocythereis coronata was also found in the Hadsten boring (see below). It is a widespread benthonic marine species in the Mediterranean, but is also found on the North Atlantic coast south of Northwest Scotland (Athersuch 1978). There are no records of Pt. coronata from the North Sea and it has not previously been found in interglacial deposits in Northwest Europe. Cytheropteron crassipinatum was classified by Whatley \& Masson (1979) as a boreal species whose geographical range is between $50^{\circ} \mathrm{N}$ and $60^{\circ} \mathrm{N}$ off the west coast of Europe.

The above-mentioned taxa constitute only a small fraction of the total fauna at Rugård. While some of these species inhabit relatively deep water in the Skagerrak and Kattegat today (Elofson 1941), no modern ostracod fauna in that area exactly matched the Rugård material. Elofson, however, observed faunas which were not unlike the Rugård assemblages between $20 \mathrm{~m}$ and $50 \mathrm{~m}$ depth. The Ostracoda at Rugård may, thus, indicate cold temperate, marine waters of over $20 \mathrm{~m}$ to $30 \mathrm{~m}$ depth, but probably shallower than $50 \mathrm{~m}$. 


\section{Hadsten}

Marine deposits have also been recorded at the base of a $74 \mathrm{~m}$ deep boring at Hadsten, East Jutland (Geol. Surv. File no. 78.458) (fig. 1). These sediments, which occurred between $69 \mathrm{~m}$ and $74 \mathrm{~m}$ depth $(31 \mathrm{~m}$ to $36 \mathrm{~m}$ below mean sea-level), were divided into a basal silty clay possessing arctic Foraminifera, overlain by fine sand and silty clay containing boreal foraminiferal assemblages (Knudsen 1987). Knudsen considered the basal clay to have been deposited in the Late Elsterian, and the overlying sediments to belong to the Holsteinian interglacial.

\section{Ostracoda}

Only the upper two of the four samples examined by Knudsen (1987) contained Ostracoda (fig. 7). The species composition was reminiscent of that recorded at Rugård (fig. 6). Elofsonella concinna dominated the assemblages (65\% to $74 \%$ ), and Sarsicytheridea bradii, $S$. punctillata, Acanthocythereis dunelmensis, and Robertsonites tuberculatus were also recorded at both sites. Of interest was the presence of Carinocythereis whitei, which was also found in foraminiferal zone E at Tornskov (fig. 3), and Pterygocythereis coronata.

\section{Palaeoenvironment}

Only adult carapaces and valves were found in the Hadsten material. This, coupled with the fact that many of the specimens were etched and stained red, suggested that relatively high energy conditions existed at the site. Species composition indicated the pres-

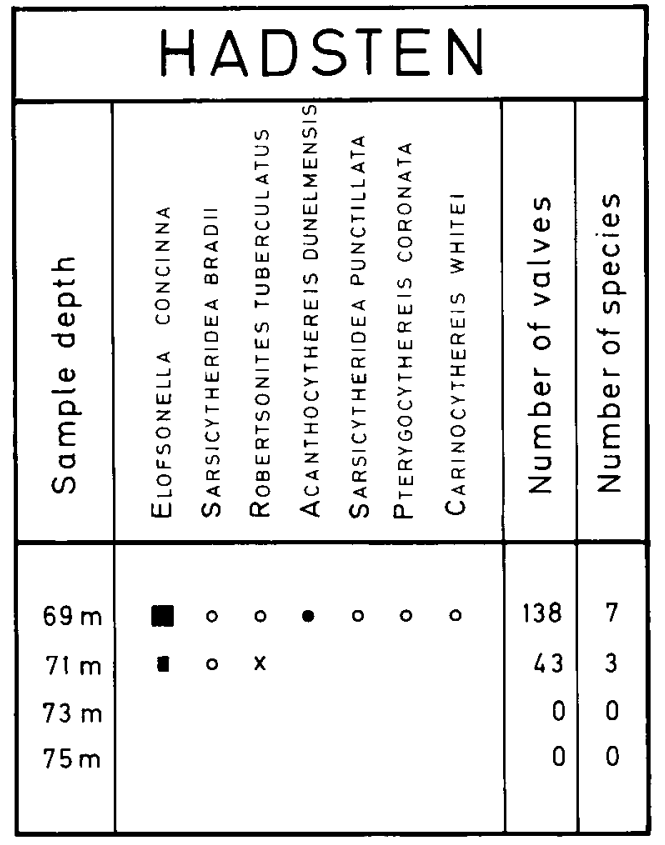

Fig. 7. Distribution of Ostracoda in Holsteinian marine deposits in the Hadsten boring. Sample numbers are the same as those given in Knudsen 1987. The symbols are explained in fig. 2.

ence of relatively open, sublittoral conditions and normal marine salinities. The marine deposits at Hadsten are probably glacially deformed, and may have been transported as a frozen block from the east. This deposit's location in East Jutland is, nonetheless, of interest, as it could indicate that an open sound existed across North Jutland during the Late Elsterian and Holsteinian, connecting the North Sea to the Kattegat. 


\section{Age and correlation}

Recent advances in absolute dating techniques have meant that we can now be fairly sure of the stratigraphic position of several interglacial marine deposits in Denmark. Thus, Tornskov, Rugård, and Kås Hoved have all been assigned to the Holsteinian interglacial on the basis of amino-acid and thermoluminescence measurements (Miller \& Mangerud 1986, Knudsen 1987). More traditional methods must be resorted to where absolute dates are unavailable. The interglacial deposits at Inder Bjergum have, for example, been assigned to the Holsteinian on the basis of their pollen (Andersen 1963) and foraminiferal (Buch 1955, Knudsen this volume) content, and because they are overlain by Eemian marine sediments (Buch 1955). The interglacial deposits at Hadsten have also been placed in the Holsteinian on the basis of their foraminiferal content (Knudsen 1987).

Considerable uncertainty lies in the use of biological correlation techniques in Quaternary stratigraphy, not least because very few genuine extinction events are recognisable in the Pleistocene. Thus, presence/absence data largely reflect environmental control rather than genetic (=evolutionary) events. The apparent similarity in the biological composition of assemblages from two or more deposits need not, therefore, necessarily mean that they are of the same age. Minor differences do, however, often occur, and these can be used productively to distinguish between interglacials. Thus, considerable steps have been made to differentiate between Eemian marine deposits and sediments belonging to earlier interglacials using Foraminifera (Knudsen 1986).

Unfortunately, no such advances have been forthcoming for Ostracoda, as they have not been examined in detail in the Danish Eemian. I have studied some borehole material from the marine Eemian embayment in Southwest Jutland (see fig. 8), but the deposits here are from the intertidal environment, and cannot, therefore, be compared directly with the shallow, sublittoral sediments of the Danish Holsteinian. Deeper water Eemian deposits occur in North Jutland (e.g. Bahnson et al. 1974), but their ostracod content remains to be examined. Two samples from a sublittoral facies of the Eemian, from a boring at Nørre

\begin{tabular}{|l|c|r|r|r|}
\hline \multirow{2}{*}{ Species } & \multicolumn{2}{|c|}{ Sample no. 83 } & \multicolumn{2}{c|}{ Sample no. 84 } \\
& c & \multicolumn{2}{|c|}{ c } & \multicolumn{2}{|c|}{ v } \\
\hline Sarsicytheridea punctillata & 1 & 61 & 4 & 150 \\
Acanthocythereis dunelmensis & - & 33 & 2 & 15 \\
Elofsonella concinna & - & 1 & - & 3 \\
Krithe pernoides & - & 2 & 1 & - \\
Palmoconcha laevata & 1 & - & - & - \\
Normanicythere leioderma & - & - & - & 2 \\
\hline Total & 2 & 97 & 7 & 170 \\
\hline
\end{tabular}

Table 1.: Nørre Lyngby Eemian deposits: species list and abundances $(\mathrm{c}=$ carapaces, $\mathrm{v}=$ valves $)$. 


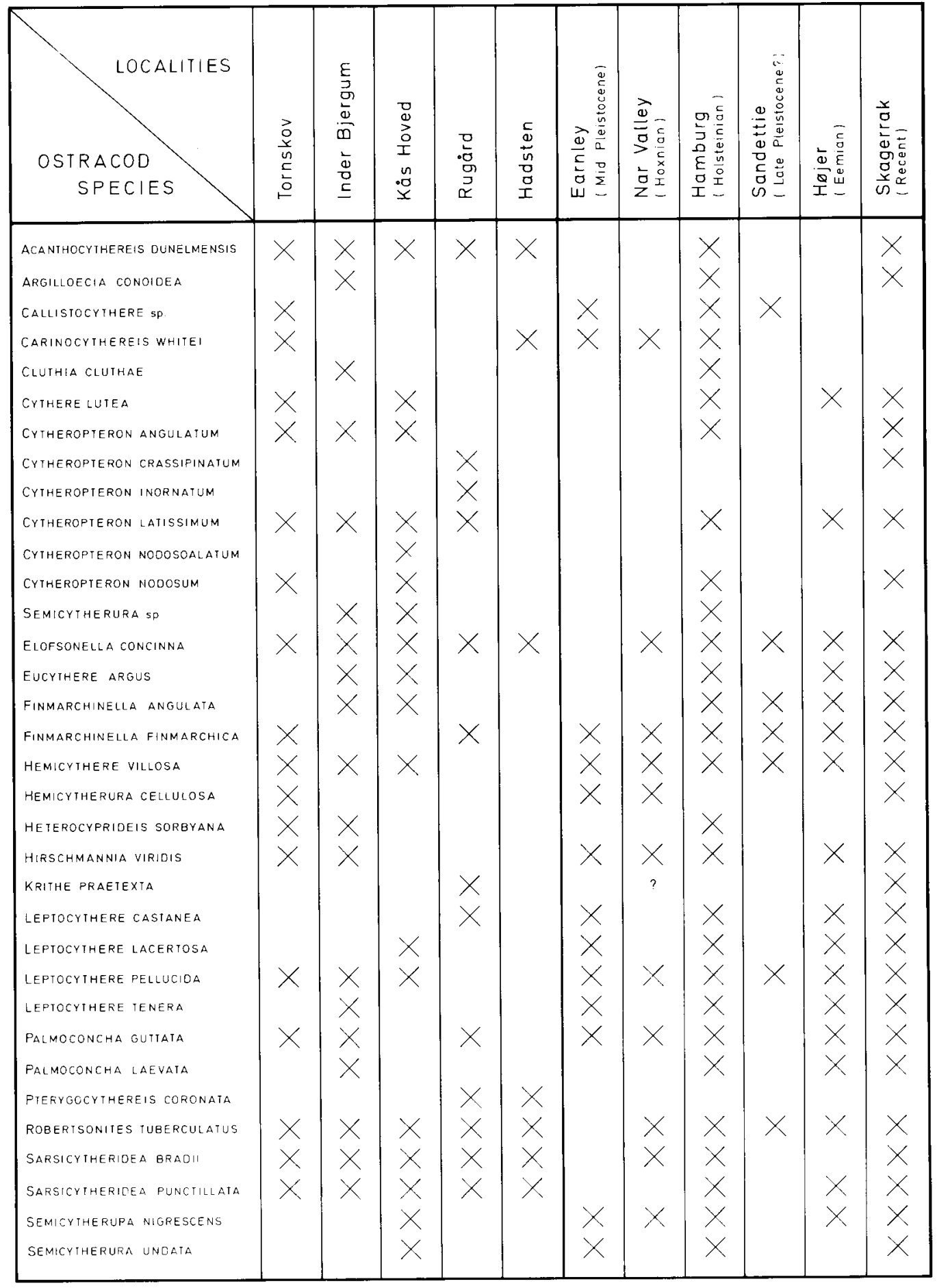

Fig. 8. Ostracod distribution by age and site. Sources: Tornskov, Inder Bjergum, Kås Hoved, Rugård, and Hadsten - this study; Earnley - West et al. 1984; Nar Valley - Lord \& Robinson 1978 and West et al. 1984; Hamburg - Woszidlo 1962 and Lord, Robinson and Moutzourides in-press; H申jerPenney unpublished data; Skaggerak - Elofson 1941 and Sars 1928.

4 DGU serie B nr. 10 
Lyngby (fig. 1), were kindly placed at my disposal by Anne-Lise Lykke-Andersen. These contained ostracod assemblages (Table 1) which were rather similar in species composition to those recorded at $\mathrm{Ru}$ gård (fig. 6), but which lacked Robertsonites tuberculatus. In addition, the Nørre Lyngby material was dominated by Sarsicytheridea punctillata, whereas Elofsonella concinna dominated the Rugård assemblages. It is not clear if these differences are of any significance in distinguishing between the Holsteinian and Eemian interglacials, as the possibility remains that they are simply the result of a combination of facies, water depth, and temperature controls.

The ecological patterns discussed in the first part of this paper are based on the evidence drawn from the vast majority of species on the faunal list (fig. 8). Nearly all of these species are alive today, but a few are not part of the living faunas in Danish inshore waters. The latter include species which have their present northern limits of distribution in South Britain, and at least one which may be extinct. Both categories may tell us something about the relative age of the Tornskov, Inder Bjergum, Kås Hoved, Rugård, and Hadsten deposits.

Of the species which can suggest an age, several bear a striking resemblance to those found in the Hoxnian (Holsteinian) Nar Valley Clays of East England (e.g. Lord \& Robinson 1978) and the Holsteinian marine deposits of the Hamburg area, North Germany (Woszidlo 1962, Lord et al. in-press). One such form is Carinocythereis whitei, a warm water indicator, which was present at Tornskov (foraminiferal zone E) and Hadsten (figs 2 and 7). This is actually the senior synonym of both $C$. aspera (Brady) and $C$. bairdii Uliczny (see Athersuch et al. 1985). It has also been recorded in the Mid-Pleistocene (Late Cromerian-Late Hoxnian) estuarine deposits at Earnley (Robinson, in West et al. 1984), but has not been found in the Eemian deposits of Great Britain (e.g. Whatley, in Kidson et al. 1978, Whatley \& Kaye 1971).
The undescribed Callistocythere species found in the Tornskov boring (fig. 2) has also been recorded at Earnley (Robinson, in West et al. 1984), Dockenhuden (qho 4) in the Hamburg area (Lord et al. in-press), the Red Crag of Great Britain, and the graded sediments of the ?Late-Pleistocene Sandettie-Fairey Bank in the English Channel (Whittaker, in Kirby \& Oele 1975, Robinson, in West et al. 1984). It has not been recorded live, its present known stratigraphic range spanning the Early Pleistocene Red Crag to the ?Holsteinian interglacial.

The undescribed Semicytherura species is very close to what Lord et al. (in-press) called Semicytherura sp. A from the Holsteinian of Hamburg. This species has only been found in Holsteinian sediments todate.

There are no published records of Pterygocythereis coronata from the Pleistocene of Northwest Europe, its known range spanning only the Sub-recent and Recent (Athersuch 1978). Pt. coronata is actually the senior synonym of $P t$. siveteri Athersuch (see Malz \& Jellinek 1984). As it was previously considered as either conspecific with Pt. ceratoptera (Bosquet), or as a sub-species or variety of Pt. jonesii (Baird), the possibility remains that it has been grouped under these species-names in the Quaternary. It is widespread in the Plio-Pleistocene and Recent of the Mediterranean Sea (Athersuch 1978, Breman 1976).

Palmoconcha guttata occurred as the finely punctate Scandinavian form in the Danish Holsteinian. The same finely punctate form was also recorded in the Holsteinian deposits of North Germany (Woszidlo 1962, Lord et al. in-press), in the Mid-Pleistocene deposits at Earnley (Robinson, in West et al. 1984), and the Hoxnian Nar Valley clays (Robinson, in West et al. 1984: Table 2) (fig. 8). I have found coarsely reticulate and intermediate forms of this species in the Eemian deposits of Southwest Jutland, but only the finely punctate form is part of the Danish fauna today.

The two arctic species Cluthia cluthae and 


\begin{tabular}{|l|r|r|r|}
\hline Species & $\mathrm{c}$ & $\mathrm{v}$ & $\%$ \\
\hline Elofsonella concinna & 2 & 512 & 57 \\
Sarsicytheridea punctillata & - & 222 & 24 \\
Acanthocythereis dunelmensis & - & 74 & 8 \\
Heterocyprideis sorbyana & - & 26 & 3 \\
Cytheropteron latissimum & - & 16 & 2 \\
Finmarchinella angulata & - & 15 & 2 \\
Cluthia cluthae & - & 14 & 2 \\
Cytheropteron nodosum & - & 11 & 1 \\
Semicytherura sp. & - & 6 & - \\
Cytheropteron nodosoalatum & - & 4 & - \\
Robertsonites tuberculatus & - & 3 & - \\
Argilloecia conoidea & - & 1 & - \\
\hline Total & & & \\
\hline
\end{tabular}

Table 2. Sebberkloster, sample no. 18-21 (40 g sediment): species list and abundances ( $c=$ carapaces, $v$ $=$ valves).

Heterocyprideis sorbyana are not found alive in Danish waters today. They occurred both immediately below and above the Elsterian-Holsteinian boundary in the Inder Bjergum boring (fig. 3), and have also been found immediately below the same boundary in a boring at Sebberkloster in North Jutland (fig. 1). The latter material contained an ostracod assemblage which had a striking resemblance to that recorded in sample no. 20, just under the Elsterian-Holsteinian boundary at Inder Bjergum (compare fig. $4 \&$ Table 2). Both these species have been recorded in a similar stratigraphic position at Eggstedt in North Germany (Lord et al. in-press). Another feature in common for both Eggstedt and Inder Bjergum was the overlap in distribution of $C$. cluthae with its temperate equivalent, Leptocythere. Indeed, the ostracod assemblages of the Danish and North German Holsteinian were very similar in both species and assemblage composition, and in their sparsity. Acanthocythereis dunelmensis, Cytheropteron latissimum, Elofsonella concinna, Palmoconcha guttata, Robertsonites tuberculatus, Sarsicytheridea bradii, and $S$. punctillata were important members of the faunas in both regions. In addition, the faunal succession found by Lord et al. (in-press) in the Eggstedt boring was the same as that recorded at Inder Bjergum (fig. 4), while the ostracod assemblages present in the Dockenhuden boring corresponded more closely to those found in foraminiferal zones $\mathrm{D}$ and E at Tornskov (fig. 2). Comparison can also be made with the Hoxnian assemblages of the Nar Valley clays (Lord \& Robinson 1978), although Carinocythereis white $i$ was a much more important species in the English material.

The species considered above as possible characteristic species for the Holsteinian of Denmark constitute only $15 \%$ of the total fauna, the remainder ranging on to be part of the living ostracod fauna of Denmark. My preliminary investigations of the Eemian sequence in Southwest Jutland have not yielded a single 'extinction' to-date. These figures correspond closely to those given by Robinson (in West et al. 1984) for the Mid-Pleistocene, Eemian, and Recent of southern Britain. It is interesting to note that in the faunas of the Danish and North German Holsteinian, species that are not now part of the living fauna of the region are to be found either off southern Britain to the south or East Finmark to the north. As Robinson (in West et al. 1984) stated, to some extent this may be a response of climatic changes, resulting in faunal displacements north and south, with some species failing to migrate and readjust ecologically. 


\section{Species list}

The ostracod species present in the marine Holsteinian deposits of Jutland are listed alphabetically below. A total of 35 species were found, nine of which are illustrated in Plates 1 and 2.

Acanthocythereis dunelmensis (Norman 1865) - Pl. 2, figs. 9, 10

Argilloecia conoidea Sars 1928

Callistocythere sp. - Pl. 1, figs 1, 2

Carinocythereis whitei (Baird 1850) - Pl. 1, figs 3-6

Cluthia cluthae (Brady, Crosskey and Robertson 1874) - Pl. 1, figs 7, 8

Cythere lutea $\mathrm{O}$. F. Müller 1785

Cytheropteron angulatum Brady and Robertson 1872

Cytheropteron crassipinatum Brady and Norman 1888 - Pl. 1, fig. 9

Cytheropteron inornatum Brady and Robertson 1872 - Pl. 1, fig. 10

Cytheropteron latissimum (Norman 1865)

Cytheropteron nodosoalatum Neale and Howe 1973

Cytheropteron nodosum Brady 1868

Elofsonella concinna (Jones 1856)
Eucythere argus (Sars 1866)

Finmarchinella (Barentsovia) angulata (Sars 1866)

Finmarchinella (Finmarchinella) finmarchica (Sars 1866)

Hemicythere villosa (Sars 1866)

Hemicytherura cellulosa (Norman 1865)

Heterocyprideis sorbyana (Jones 1856)

Hirschmannia viridis (O. F. Müller 1785)

Krithe praetexta (Sars 1866)

Leptocythere castanea (Sars 1866)

Leptocythere lacertosa (Hirschmann 1912)

Leptocythere pellucida (Baird 1850)

Leptocythere tenera (Brady 1868)

Palmoconcha guttata (Norman 1865) - Pl. 2, figs 7,8

Palmoconcha laevata (Norman 1865)

Pterygocythereis coronata (Roemer 1838) Pl. 2, figs $1-4$

Robertsonites tuberculatus (Sars 1866)

Sarsicytheridea bradii (Norman 1865)

Sarsicytheridea punctillata (Brady 1865)

Semicytherura nigrescens (Baird 1838)

Semicytherura sella (Sars 1866)

Semicytherura undata (Sars 1866)

Semicytherura sp. - Pl. 2, figs. 5, 6 


\section{Conclusions}

Evidence from the ostracod faunas indicates convincingly that the Holsteinian marine sediments at the five sites considered above were all deposited under relatively open water, sublittoral conditions and normal marine salinities. Brackish water ostracod assemblages have not been recorded in the Danish Holsteinian to-date. The oysterbearing clays at Rugård were deposited in slightly deeper waters than at the other sites.

Although the examined material contained mainly sparse ostracod assemblages, certain distinct characteristics were observed which may prove to be useful for correlation purposes.

(1) Arctic and boreal-arctic species occurred together with some temperate species both above and below the late Elsterian-Holsteinian boundary, thus making it difficult to position the boundary exactly using Ostracoda. Of particular interest, however, was the overlap in distribution of the arctic Cluthia cluthae with its temperate equivalent, Leptocythere, and the occurrence of both Palmoconcha guttata and Cytheropteron latissimum below the boundary.

(2) Boreal-arctic and boreal species dominated the Danish Holsteinian faunas. These included Robertsonites tuberculatus, Elofsonella concinna, Sarsicytheridea bradii, $S$. punctillata, and Cytheropteron latissimum, while Acanthocythereis dunelmensis died out early on in the interglacial.

(3) Certain temperate species, which have their present northern limits of distribution in southern Britain, occurred later in the interglacial. These included Carinocythereis whitei, Pterygocythereis coronata, and Calli- stocythere $\mathrm{sp}$. The latter species has a known range from the Early Pleistocene to the Holsteinian. An undescribed Semicytherura species has only been found in the Holsteinian of North Germany and Denmark.

(4) The finely punctate form of Palmoconcha guttata has been found in both the Holsteinian and Recent of Denmark, whereas the coarsely reticulate form of this species has only been recorded in the Eemian of Southwest Jutland.

(5) The ostracod assemblages of the Danish Holsteinian are similar to those present in the Holsteinian of North Germany (Woszidlo 1962, Lord et al. in-press), and are not unlike those found in the Hoxnian Nar Valley clays of East England (e.g. Lord \& Robinson 1978). Eemian deposits in Northwest Europe do not contain the same faunas, but there are problems in comparing the two interglacials, as the Eemian ostracod lists have largely been derived from intertidal deposits, whereas the Holsteinian lists are from shallow, sublittoral environments. Moreover, very few ostracod studies have been undertaken on marine interglacial deposits in Northwest Europe in general, thus making it very difficult to compare and correlate between sites.

These characteristics may be specific for the Holsteinian, and may, therefore, be useful in Quaternary stratigraphical studies of interglacial marine deposits. In particular, the proportion of extant species absent from Danish waters today can probably be used as a guideline to differentiate between interglacials. 


\section{Acknowledgements}

I would like to thank the Geological Survey of Denmark for providing most of the material studied. Thanks also to Karen Luise Knudsen (Århus) and Anne-Lise LykkeAndersen (Århus) for placing material at my disposal. I am grateful to Karen Luise Knudsen, Alan Lord (University College
London), and Eric Robinson (University College London) for advice and discussion, and for allowing access to unpublished data. Jette Gissel Nielsen prepared the figures and Svend Meldgaard Christiansen the photographs for the plates. 


\section{Dansk sammendrag}

Ostrakoder i Holstein Interglaciale aflejringer i Jylland, Danmark.

Der er undersøgt ostrakod-faunaer fra fem forskellige Holstein Interglaciale lagserier $i$ Jylland: Tornskov og Inder Bjergum i SV Jylland, Kås Hoved i Limfjordsområdet og

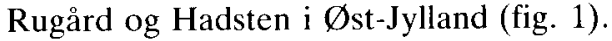

Der findes kun meget få ostrakoder i Tornskov boringen. Sen Elster aflejringerne ved bunden af boringen (Foraminifer-zoncrne A og B), samt en stor del af foraminifer-zone D er tomme (fig. 3). Ostrakoder blev først truffet i zone C, hvor faunasammensætningen svarer nogenlunde til recente faunaer i den nordlige Nordsøregion. Mere typiske Nords $\emptyset$-faunaer er fundet $\mathbf{i}$ bunden af foraminifer-zone D. Ostrakod-sammensætningen ved zone D-E grænsen indikerer lidt varmere forhold end $i$ Nordsøen i dag, idet der forekommer en del arter, som har deres nuværende nordligste udbredelse syd for England.

Relativt åbne marine forhold er afspejlet gennem hele lagserien. Dette passer godt med de faunistiske tolkninger baseret på foraminifererne.

Det glacialt forstyrrede lag ved toppen af boringen indeholder ostrakod-faunaer, som ligner de faunaer, der er fundet ved bunden af foraminifer-zone D. Ostrakoderne i den marine Holstein lagserie ved Inder Bjergum (fig. 4) svarer til dem, som er fundet i den nedre del af Tornskov serien, men ved Inder Bjergum forekommer desuden ostrakoder under Elster-Holstein grænsen. De sidstnævnte viser, at et ret koldt miljø har eksisteret $\mathrm{i}$ området før interglacialens begyndelse. Fauna-sammensatningen er næsten den samme under og over grænsen, og det er derfor vanskeligt at placere grænsen nøje med ostrakoder alene. Små ændringer viser dog, at der er en gradvis ændring fra et subarktisk til borealt miljø.

Et tilsvarende borealt miljø er repræsenteret i Holstein aflejringer ved Kås Hoved i Limfjordsområdet (fig. 3).

De ostrakod-faunaer, som er fundet ved

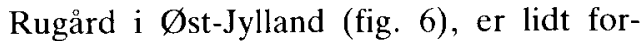
skellige fra faunaerne ved de andre lokaliteter. Her er fundet arter, der tyder på lidt dybere vand, måske mellem $30 \mathrm{og} 50 \mathrm{~m}$ dybde. Her, og i Hadsten boringen (fig. 7), er der også fundet arter, som indikerer et lidt varmere miljø end i det nuværende Kattegat.

Det er meget vanskeligt at sammenligne Holstein ostrakod-faunaer med faunaer fra andre interglacialer, fordi kun fả undersøgelser er publiceret indtil nu, men der forekommer nogle specielle fauna-sammensatninger og arter i de danske marine Holstein lag, som kan være af biostratigrafisk betydning.

Følgende punkter kan fremhæves på nuværende tidspunkt:

1. Arktiske og boreal-arktiske ostrakoder er fundet sammen ved Elster-Holstein grænsen. Af speciel interesse er tilstedeværelse af den arktiske Cluthia cluthae sammen med de tempererede Leptocythere spp., Palmoconcha guttata og Cytheropteron latissimum.

2. Boreal-arktiske og boreale arter dominerer det danske Holstein. Vigtige arter er Robertsonites tuberculatus, Elofsonella concinna, Sarsicytheridea bradii, $S$. punctillata og Cytheropteron latissimum, mens Acanthocythereis dunelmensis kun er fundet tidligt $\mathrm{i}$ interglacialen. 
3. I det danske Holstein optræder nogle tempererede arter som ikke er fundet $\mathrm{i}$ dag nord for Syd- og Vest-England. Vigtige arter er Carinocythereis whitei, Pterygocythereis coronata og en ubeskrevet art af Callistocythere. Sidstnævnte art og en ubeskrevet Semicytherura art er mulige ledefossiler for det Nord-Europæiske Holstein.

4. Den fint-punkterede form af Palmoconcha guttata er udbredt i Holstein og i recente aflejringer i Danmark, mens den groft-punkterede form af arten kun er fundet i Eem.
5. De danske ostrakod-faunaer ligner de faunaer, der er fundet i tilsvarende lagserier i Nord-Tyskland, og de kan også sammenlignes med mellem-Pleistocæne interglaciale faunaer i England.

Man skal imidlertid være forsigtig med at anvende ovennævnte karakteristika som eneste baggrund for en stratigrafisk tolkning. Men når resultaterne koordineres med foraminifer- og. pollenanalyser og støttes at nogle dateringer, er der gode muligheder for at få et rimeligt sikkert stratigrafisk resultat. 


\section{References}

Andersen, S. T., 1963: Pollen Analysis of the Quaternary Marine Deposits at Tornskov in South Jutland. Danm. geol. Unders. IV Rakke 4 (8), 1-23.

Andersen, S. T., 1965: Interglacialer og interstadialer i Danmarks kvartær. Medd. dansk geol. Foren. 15 (4), 486-504.

Athersuch, J., 1978: On Pterygocythereis siveteri Athersuch sp. nov. Stereo-Atlas Ostracod Shells 5 (1), 1-8.

Athersuch, J., 1982: Some ostracod genera formerly of the Family Cytherideidae Sars. 231-275 in: Bate, R. H., Robinson, E. \& Sheppard; L. M. (editors): Fossil and Recent Ostracods. Ellis Horwood, Chichester.

Athersuch, J., Horne, D. J. \& Whittaker, J. E., 1985: G. S. Brady's Pleistocene ostracods from the Brickearth of the Nar Valley, Norfolk, U.K. J. micropalaeontol. 4 (2), 153-158.

Bahnson, H., Petersen, K. S., Konradi, P. B. \& Knudsen, K. L., 1974: Stratigraphy of Quaternary deposits in the Skarumhede II boring: lithology, molluscs and foraminifera. Danm. geol. Unders., Årbog 1973, 27-62.

Bassiouni, M. el A. A., 1965: Über einige Ostracoden aus dem Interglazial von Esbjerg. Medd. dansk geol. Foren. 15 (4), 507-518.

Bonaduce, G., Ciampo, G. \& Masoli, M., 1975: Distribution of Ostracoda in the Adriatic Sea. Pubbl. Staz. zool. Napoli 40, 1 Suppl., 1-154.

Breman, E., 1976: The distribution of ostracodes in the bottom sediments of the Adriatic Sea. Academisch Proefschrift, Vrije Universiteit, Amsterdam, 1-165.

Buch, A., 1955: De marine interglaciale lag ved Inder Bjergum. Foraminiferfauna og stratigrafi. Medd. dansk geol. Foren. 12 (6), 593-652.

Catt, J. A. \& Penny, L. F., 1966: The Pleistocene Deposits of Holderness, East Yorkshire. Proc. Yorks. Geol. Soc. 35, 375-420.

Colhoun, E. A. \& Mitchell, G. F., 1971: Interglacial marine formation and Late-glacial freshwater formation in Shortalstown Townland, Co. Wexford. Proc. R. Ir. Acad. 71B, 211-245.

Edwards, C. A., 1982: The Speeton Shell Bed. Quat. Newsletter 36, 3-9.

Elofson, E., 1941: Zur Kenntnis der marinen Ostracoden Schwedens mit besonderer Berücksichtung des Skagerraks. Zool. Bidr. Upps. 19, 215534.
Hansen, S., 1965: The Quaternary of Denmark. 1-90 in: Rankama, K. (editor): The Geological Systems. The Quaternary 1. International publishers, New York.

Hirschmann, N., 1912: Beiträge zur Kenntnis des Ostracoden-Fauna des Finnischen Meerbusen. Acta. Soc. Fauna Flora fenn. 36 (2), 3-65.

Jensen, J. B. \& Knudsen, K. L., 1984: Kvartærstratigrafiske undersøgelser ved Gyldendal og Kås Hoved i det vestlige Limfjordsområde. Dansk geol. Foren., Årsskrift for 1983, 35-54.

Kidson, C., Gilbertson, D. D., Haynes, J. R., Heyworth, A., Hughes, C. E. \& Whatley, R. C. 1978 : Interglacial marine deposits of the Somerset Levels, South-west England. Boreas 7 (4), 215-228.

Kirby, R. \& Oele, E. 1975: The Quaternary History of the Sandettie-Fairey Bank area, southern North Sea. Phil. Trans. R. Soc. Lond. A279, 257267.

Knudsen, K. L., 1986: Middle and Late Quaternary foraminiferal stratigraphy in the southern and central North Sea area. Striae 24, 201-205.

Knudsen, K. L., 1987: Elsterian-Holsteinian foraminiferal stratigraphy in the North Jutland and Kattegat areas, Denmark. Boreas, in-press.

Kronborg, C. \& Knudsen, K. L. 1985: Om Kvartæret ved Rugărd: En foreløbig undersøgelse. Dansk geol. Foren., Årsskrift for 1984, 37-48.

Lord, A. R., 1980: Weichselian (Late Quaternary) ostracods from the Sandnes Clay, Norway. Geol. Mag. 117 (2), 227-242.

Lord, A. R. \& Robinson, J. E., 1978: Marine Ostracoda from the Quaternary Nar Valley Clay, West Norfolk. Bull. geol. Soc. Norfolk 30, 113 118.

Lord, A. R., Robinson, J. E. \& Moutzourides, S. $\mathrm{G}$., in-press: Ostracoda from Holsteinian deposits in the Hamburg area. Geol. Jb.

Malz, H. \& Jellinek, J., 1984: Marine Plio-/Pleistozän-Ostracoden von SE-Lakonien (Peloponnes, Griechenland). Senckenbergiana biol. 65 (1/2), 113-167.

Meldgaard, S. \& Knudsen, K. L., 1979: Metoder til indsamling og oparbejdning af prøver til foraminiferanalyser. Dansk Natur-Dansk Skole, Årsskrift 1979, 48-57.

Miller, G. H. \& Mangerud, J., 1986: Aminostratigraphy of European Marine Interglacial deposits. Quaternary Science Reviews 4 (4) (for 1985), 215278. 
Neale, J. W., 1973: Cluthia (Crustacea, Ostracoda), a new Pleistocene and Recent Leptocytherid Genus. J. Paleont. 47 (4), 683-688.

Neale, J. W., 1974: Ostracod faunas from the Celtic Sea. Geoscience \& Man 6, 81-98.

Neale, J. W., 1975: On Cluthia keiji Neale, sp. nov. Stereo-Atlas Ostracod Shells, 2 (3), 141-148.

Neale, J. W. \& Howe, H. V., 1975: The marine ostracoda of Russian Harbour, Novaya Zemlya and other high latitude faunas. Bull. Amer. Paleont. $65,381-431$.

Norman, A. M., 1891: Notes on the marine Crustacea Ostracoda of Norway. Ann. Mag. nat. Hist. ser. 6, 7, 108-121.

Rosenfeld. A., 1977: Die rezenten Ostracoden-Arten in der Ostsee. Meyniana 29, 11-49.

Sars, G. O., 1928: An Account of the Crustacea of Norway, Vol. 9: Ostracoda. 1-277. Bergen Museum.
West, R. G., Devoy, R. J. N., Funnell, B. M. \& Robinson, J. E., 1984: Pleistocene Deposits at Earnley, Bracklesham Bay, Sussex, Phil. Trans. R. Soc. Lond. B306, 137-157.

Whatley, R. C., 1983: The Application of Ostracoda to palaeoenvironmental analysis. $51-77$ in: Maddocks, R. F. (editor): Applications of Ostracoda. University of Houston, Geoscience.

Whatley, R. C. \& Kaye, P., 1971: The Palaeoecology of Eemian (Last Interglacial) Ostracoda from Selsey, Sussex. Bull. Centre Rech. Pau-SNPA. 5 Suppl. 311-330.

Whatley, R. C. \& Masson, D. G., 1979: The ostracod Genus Cytheropteron from the Quaternary and Recent of Great Britain. Revista Española Micropaleont. 11 (2), 223-278.

Woszidlo, H., 1962: Foraminiferen und Ostracoden aus dem marinen Elster-Saale-Interglazial in Schleswig-Holstein. Meyniana 12, 65-96. 
Plates 1-2 
PLATE 1

Scale $=100 \mu \mathrm{m}$

Fig. 1. Callistocythere sp. Left valve, external lateral view, adult (450 $\mu \mathrm{m}$ long). Tornskov 159.243, sample No. 14.

Fig. 2. Callistocythere sp. Left valve, internal lateral view, adult (460 $\mu \mathrm{m}$ long). Tornskov 159.243, sample No. 18.

Fig. 3. Carinocythereis whitei (Baird, 1850). Right valve, external view, juvenile A-1 (757 $\mu \mathrm{m}$ long). Tornskov 159.243, sample No. 44.

Fig. 4. Carinocythereis whitei (Baird, 1850). Left valve, external lateral view, juvenile A-1 (767 $\mu \mathrm{m}$ long). Tornskov 159.243, sample No. 44.

Fig. 5. Carinocythereis whitei (Baird, 1850). Right valve, external lateral view, male (838 $\mu \mathrm{m}$ long). Hadsten 78.458, sample No. 69.

Fig. 6. Carinocythereis whitei (Baird, 1850). Left valve, external lateral view, male (862 $\mu \mathrm{m}$ long). Hadsten 78.458, sample No. 69.

Fig. 7. Cluthia cluthae (Brady, Crosskey \& Robertson, 1874). Right valve, external lateral view, female (385 $\mu \mathrm{m}$ long). Inder Bjergum 140.82b, sample No. 18.

Fig. 8. Cluthia cluthae (Brady, Crosskey \& Robertson, 1874). Left valve, external lateral view, female (359 $\mu \mathrm{m}$ long). Sebberkloster 33.481, sample No. 18.21.

Fig. 9. Cytheropteron crassipinatum Brady \& Norman, 1888. Right valve, external lateral view, adult (382 $\mu \mathrm{m}$ long). Rugård, sample No. 1b.

Fig. 10. Cytheropteron inornatum Brady \& Robertson, 1872. Right valve, external lateral view, adult (436 $\mu \mathrm{m}$ long). Rugård, sample No. Fl. 

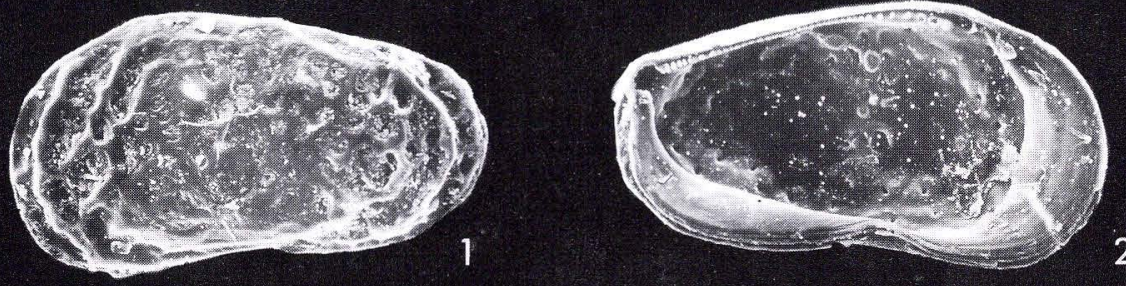

(2)

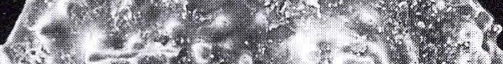

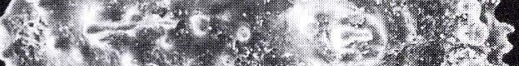

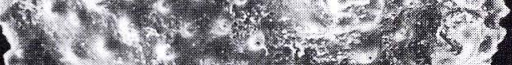

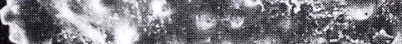

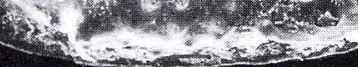
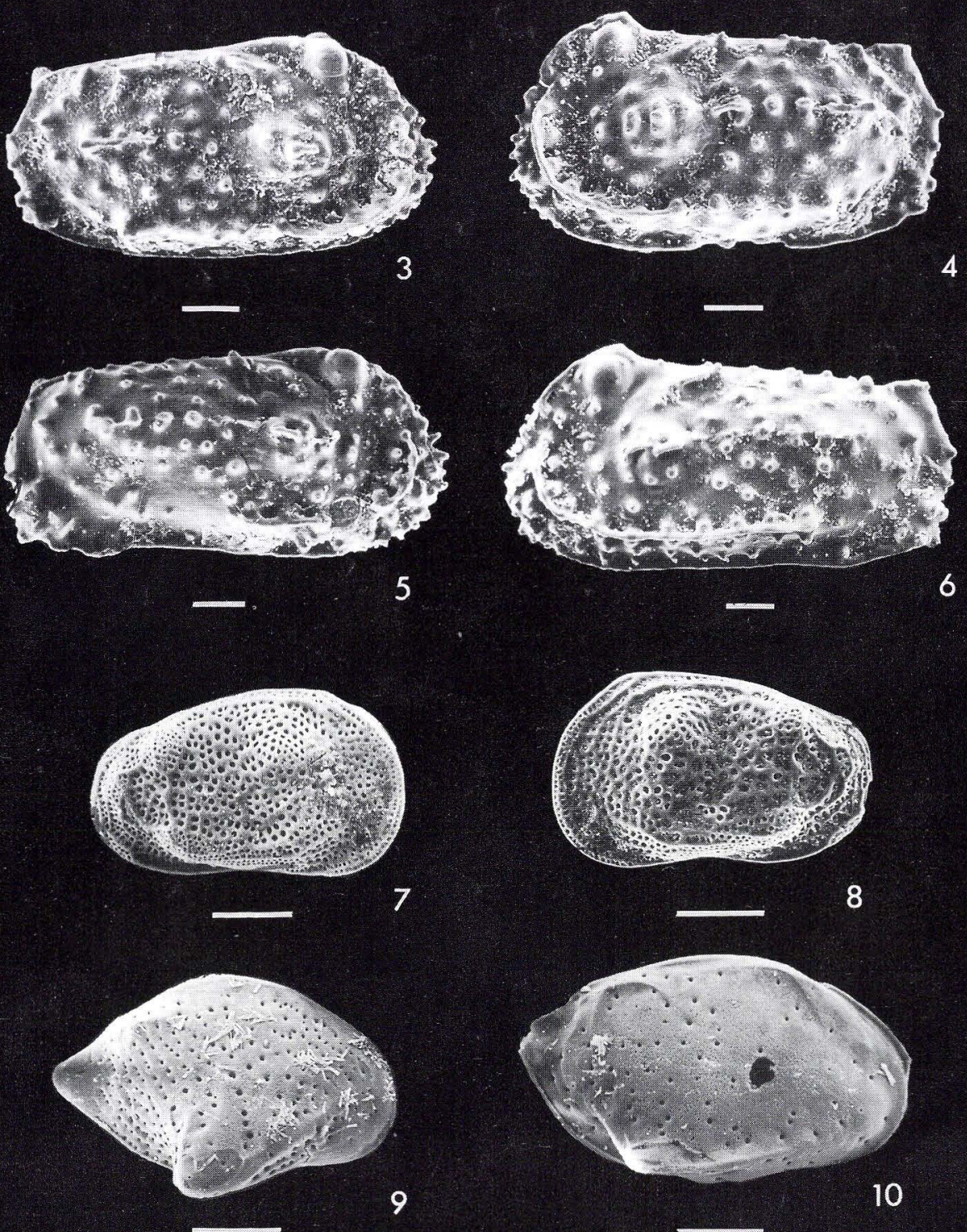

7

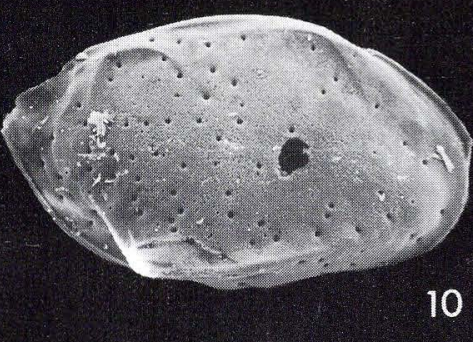


PLATE 2

Scale $=100 \mu \mathrm{m}$

Fig. 1. Pterygocythereis coronata (Roemer, 1838). Left valve, external lateral view, ?male (1045 um long). Hadsten 78.458, sample No. 69.

Fig. 2. Pterygocythereis coronata (Roemer, 1838). Right valve, external lateral view, ?male (1054 $\mu \mathrm{m}$ long). Hadsten 78.458, sample No. 69.

Fig. 3. Pterygocythereis coronata (Roemer, 1838). Left valve, external dorsal view, ?male (1045 $\mu \mathrm{m}$ long). Hadsten 78.458, sample No. 69.

Fig. 4. Pterygocythereis coronata (Roemer, 1838). Right valve, external dorsal view, ?male (1054 um long). Hadsten 78.458, sample No. 69.

Fig. 5. Semicytherura sp. Left valve, external lateral view, ?male ( $445 \mu \mathrm{m}$ long). Inder Bjergum 140.82 b, sample No. 20.

Fig. 6. Semicytherura sp. Right valve, external lateral view, ?female (441 $\mu \mathrm{m}$ long). Sebberkloster 33.481, sample No. 18-21.

Fig. 7. Palmoconcha guttata (Norman, 1865). Left valve, external lateral view, female (600 $\mu \mathrm{m}$ long). Tornskov 159.243, sample No. 42.

Fig. 8. Palmoconcha guttata (Norman, 1865). Right valve, external lateral view, female (607 $\mu \mathrm{m}$ long). Tornskov 159.243, sample No. 42.

Fig. 9. Acanthocythereis dunelmensis (Norman, 1865). Right valve, external lateral view, male (930 $\mu \mathrm{m}$ long). Inder Bjergum 140.82b, sample No. 20.

Fig. 10. Acanthocythereis dunelmensis (Norman, 1865). Right valve, external lateral view, juvenile A-1 (830 $\mu \mathrm{m}$ long). Inder Bjergum 140.82b, sample No. 17. 

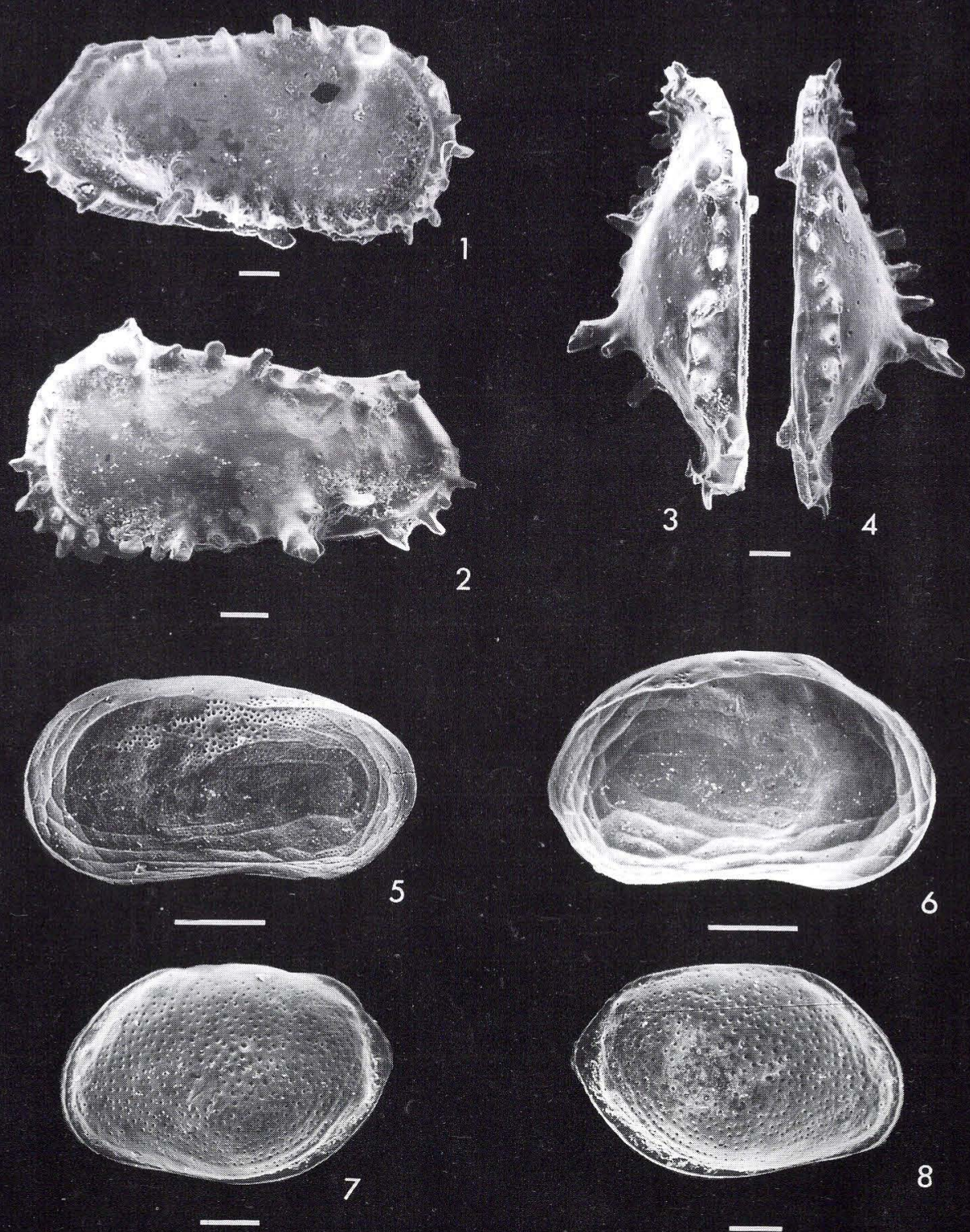

s.

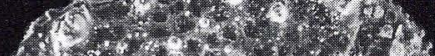

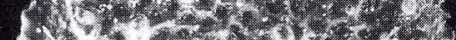

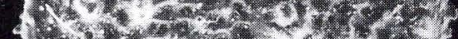

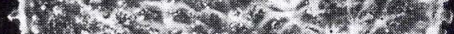

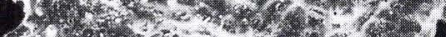

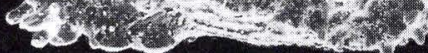

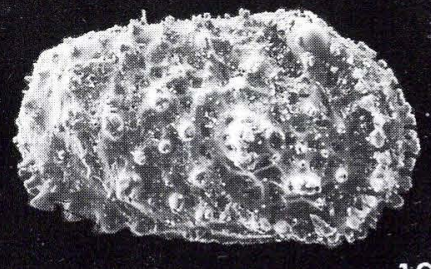

